\title{
Correlation between Inflammatory Marker and Glycemic Control in Patients with Ischemic Heart Disease
}

\author{
Mohsin Ahmed ${ }^{1}$, Md Mesbahul Islam² ${ }^{2}$ Mohammad Arifur Rahman ${ }^{3}$, Khandaker Abu Rubaiyat ${ }^{4}$, C. M Khudrate-E- \\ Khuda $^{5}$, Kazi Abul Fazal Ferdous ${ }^{6}$, Bikash Chandra Das ${ }^{7}$, Sanoat Kalam Linda ${ }^{8}$
}

\begin{abstract}
:
Background: Recent evidence suggests that inflammatory markers and poor glycemic control are significantly associated with the development of cardiovascular complications. The purpose of this study was to determine the association between inflammatory marker (CRP) and glycemic status (HbA1c) in ischemic heart disease patients.

Method: This cross sectional study was performed on 668 patients of ischemic heart disease in the Department of Cardiology, Dhaka Medical College Hospital, Dhaka, who underwent Coronary angiogram from January 2017 to December 2017. CRP value were divided into normal ( $<6 \mathrm{mg} / \mathrm{L})$, borderline $(6-10 \mathrm{mg} / \mathrm{L})$ and high (>10 mg/L) and $\mathrm{HbA} 1 \mathrm{c}$ was divided $<6.5 \%$ and $\geq 6.5 \%$. After performed Coronary angiography the extent of disease was divided into insignificant CAD of ( $<50 \%$ stenosis), significant CAD considered as $>50 \%$ stenosis and single vessel, double vessel, triple vessel CAD and normal coronaries. The relationship between CRP with HbA1c was analyzed by Chi square test. ANOVA test was used to analyze the continuous variables, shown with mean and standard deviation. Pearson's correlation coefficient was used to test the
\end{abstract}

relationship between CRP and $\mathrm{HbA1c}$ in CAD patients. $p$ value $<0.05$ was considered as statistically significant.

Result: Most $(65.0 \%)$ of the patients belonged to age 41-60 years. The mean age was found $51.4 \pm 10.7$ years. Majority $(82.3 \%)$ of patients were male. Among risk factors, highest $(\mathbf{4 0 . 0 \% )}$ patients had hypertension followed by 209 (31.3\%) diabetes mellitus and 204 (30.5\%) smoker. Positive correlation was found $(r=0.220, p=$ 0.001 ) between HbA1c with CRP in CAD patients. High CRP was found $138(38.4 \%)$ in $<6.5 \% \mathrm{HbA1c}$ and $187(60.5 \%)$ in $\geq 6.5$ percent $\mathrm{HbA1c}$. The difference was statistically significant $(p<0.05)$. Multi variable logistic regression was found high HbA1c, high CRP and diabetes mellitus were statistically significant $(p<0.05)$ in severe CAD (Double and triple vessel) patient.

Conclusion: Positive correlation was found between serum levels of CRP and HbA1c in CAD patients. Thus, aiming at good glycemic control and estimation of serum CRP levels will possibly be of help in planning early intervention, thereby preventing further complications which in turn may help preserve cardiac functions in ischemic heart disease patients.

Keywords: Coronary artery disease, C-reactive protein, $\mathrm{HbA1c}$

1. Associate Professor, Department of Cardiology, National Institute of Cardiovascular Diseases, Dhaka, Bangladesh

2. Registrar, Department of Cardiology, Ibn Sina Hospital, Dhaka, Bangladesh

3. Junior Consultant, Department of Cardiology, National Institute of Cardiovascular Diseases, Dhaka, Bangladesh

4. MD, Final Part, Department of Cardiology, Dhaka Medical College, Dhaka, Bangladesh

5. Junior Consultant, Department of Cardiology, Dhaka Medical College, Dhaka, Bangladesh

6. Medical Officer, Department of Cardiology, Dhaka Medical College, Dhaka, Bangladesh

7. Registrar, Department of Cardiology, Dhaka Medical College, Dhaka, Bangladesh

8. FCPS Part-II, Department of Medicine, Bangabandhu Sheikh Mujib Medical Unerversity, Dhaka, Bangladesh

Address of Correspondence: Dr. Mohsin Ahmed, Associate Professor, Department of Cardiology, National Institute of Cardiovascular Diseases, Dhaka, Bangladesh. Cell: +8801613393186, E-mail: mohsinsohel07@gmail.com

DOI: http://dx.doi.org/10.3329/bhj.v33i2.39305

Copyright $\odot 2017$ Bangladesh Cardiac Society. Published by Bangladesh Cardiac Society. This is an Open Access articles published under the Creative Commons Attribution-NonCommercial 4.0 International License (CC BY-NC). This license permits use, distribution and reproduction in any medium, provided the original work is properly cited and is not used for commercial purposes. 


\section{Introduction:}

The autoimmune response associated with overproduction of T helper-1 (Th1) cytokines which activate macrophage production of proinflammatory mediators interleukin-6 (IL6 ) and TNF- $\pm .{ }^{1} \mathrm{IL}-6$ is produced also by a variety of cells such as adipocytes, which produce $30 \%$ of the circulating IL-6, fibroblasts and endothelial cells. ${ }^{2}$ It mediates damage to micro- and macro-vascular tissues, altered insulin secretion either directly or through stimulation of free fatty acid production and altered glucose homeostasis. ${ }^{3} \mathrm{C}$ reactive protein is an acute-phase protein and a marker of non-specific inflammation synthesized in the liver. The biosynthesis of CRP is largely regulated by IL-6. ${ }^{4}$ Plasma markers of inflammation, such as CRP and IL-6 are positively associated with risk of vascular disease in non diabetic individuals. ${ }^{5}$ Recently, inflammation has been considered, at least in part, to lead to the development and progression of atherosclerosis. ${ }^{6}$

C-reactive protein (CRP), a marker of systemic inflammation, is emerging as an independent risk factor for cardiovascular disease. ${ }^{7-9}$ High CRP levels have been linked to an increased risk of thrombotic events including myocardial infarction. ${ }^{9-11}$ Elevated CRP levels have also been linked to an increased risk of later development of diabetes. ${ }^{12,13}$ Furthermore, CRP levels are higher in people with diabetes compared with those without diabetes. ${ }^{14-16}$ Less is known about whether CRP in people with diabetes is related to level of glycemic control. Wu et al. ${ }^{17}$ found that $\mathrm{CRP}$ is associated with $\mathrm{HbA} 1 \mathrm{c}$ levels.

Elevated glycohemoglobin A1 ( $\mathrm{HbA} 1 \mathrm{c})$ is an established predictor for developing atherosclerosis. ${ }^{18,19}$ Eeg-Olofsson et al. ${ }^{20}$ studied a total of 7,454 patients from the Swedish National Diabetes Register over a period of 5 years (aged 20-65 years, diabetes duration 1-35 years) and found a progressively increasing risk of coronary heart disease and cardiovascular diseases with higher $\mathrm{HbA} 1 \mathrm{c}$ levels independent of traditional risk factors. $\mathrm{HbA} 1 \mathrm{c}$ is a better marker for determining risks of CAD and mortality than fasting blood glucose and even non-diabetic patients with elevated $\mathrm{HbA} 1 \mathrm{c}$ levels are also at increased risk for CVD and mortality. ${ }^{21}$ Both enhanced inflammation and hyperglycemia contribute to the development and progression of atherosclerosis and are frequently found in patients with clinically advanced disease. Given the interrelation between inflammation, hyperglycemia, and atherosclerotic disease.

There was a statistically significant positive correlation of serum hsCRP levels with $\mathrm{HbA} 1 \mathrm{c}$ indicating the role of poor glycemic control. Studies have shown similar association between hyperglycemia and inflammation. ${ }^{22}$ It is known that glycation triggers the inflammatory process, leading to a rise in hsCRP levels. Thus, hsCRP can predict the onset of glycation-induced inflammatory process secondary to poor glycemic control. $^{23}$

To provide further insight into the role of inflammation in the development of cardiovascular disease, we sought to elucidate the link between level of glycemic control and inflammation. The purpose of the study was to investigate the correlation between $\mathrm{CRP}$ and $\mathrm{HbA} 1 \mathrm{c}$ in the patients with ischemic heart disease.

\section{Methodology:}

This cross sectional study was performed on 668 patients of ischemic heart disease (CSA, UA, NSTEMI and STEMI) in the Department of Cardiology, Dhaka Medical College Hospital, Dhaka, who were underwent Coronary angiography from January 2017 to December 2017. Demographic variables, such as age and sex, west and hip circumference and angiography results were recorded. After explaining the aims of the study and obtaining the patient's approval for participation blood samples were sent. CRP value were divided into normal ( $<6 \mathrm{mg} / \mathrm{L})$, borderline (6-10 mg/L) and high $(>10 \mathrm{mg} / \mathrm{L})^{19}$ and $\mathrm{HbA} 1 \mathrm{c}$ was divided $<6.5 \%$ and e"6.5\%. After performed Coronary angiography the extent of disease was divided into insignificant CAD of $(<50 \%$ stenosis), significant CAD considered as $>50 \%$ stenosis $^{20}$ and single vessel, double vessel, triple vessel CAD and normal coronaries. The relationship between CRP with $\mathrm{HbA} 1 \mathrm{c}$ was recorded by Chi square test. Statistical Package for the Social Sciences (SPSS) version 23.0 for windows was used to analyze the data. Categorical variables were expressed as proportions (percentages) and numerical data was expressed as means (standard deviations) and ranges. ANOVA test was used to analyze the continuous variables, shown with mean and standard deviation. Pearson's correlation coefficient was used to test the relationship between CRP and HbA1c in CAD patients. p value $<0.05$ was considered as statistically significant.

\section{Results:}

This cross sectional study was performed on 668 patients of ischemic heart disease (CSA, UA, NSTEMI and STEMI) in the Department of Cardiology, Dhaka Medical College Hospital, Dhaka, who were underwent Coronary angiography from January 2017 to December 2017.

Most (65.0\%) of the patients belonged to age 41-60 years. The mean age was found $51.4 \pm 10.7$ years with range from $25-85$ years. Majority ( $82.3 \%$ ) patients were male and 390 $(58.4 \%)$ patients were illiterate (Table- 1$)$. In risk factors, highest 267 (40.0\%) patients had hypertension followed by 209 (31.3\%) diabetes mellitus, 204 (30.5\%) smoker, 189 
(28.3\%) H/O ischemic heart disease and 151 (22.6\%) dyslipidemia (Table-2). Positive correlation $(r=0.220, p=$ 0.001 ) of $\mathrm{HbA} 1 \mathrm{c}$ with $\mathrm{CRP}$ (Figure 1). High CRP was found $138(38.4 \%)$ in $<6.5$ percent $\mathrm{HbA} 1 \mathrm{c}$ and $187(60.5 \%)$ in e"6.5 percent $\mathrm{HbA} 1 \mathrm{c}$. The difference was statistically significant $(p<0.05)$ (Table III). Multi variable logistic regression was found high $\mathrm{HbA} 1 \mathrm{c}$, high $\mathrm{CRP}$ and diabetes mellitus were statistically significant $(p<0.05)$ in severe CAD (Double and triple vessel) patients (Table IV).

\section{Table-I}

Demographic characteristics of the study subjects $(n=668)$

\begin{tabular}{lcc}
\hline Demographic characteristics & Frequency & Percentage \\
\hline Age (in years) & & \\
$\quad \leq 40$ & 123 & 18.4 \\
$\quad 41-60$ & 434 & 65.0 \\
$\quad>60$ & 111 & 16.6 \\
Mean \pm SDRange (min-max) & $51.4 \pm 10.7(25-85)$ & \\
Sex & & \\
$\quad$ Male & 550 & 82.3 \\
$\quad$ Female & 118 & 17.7 \\
Educational status & & \\
$\quad$ Illiterate & 390 & 58.4 \\
$\quad$ Primary & 110 & 16.5 \\
$\quad$ Secondary & 111 & 16.6 \\
$\quad$ Higher & 37 & 5.5 \\
$\quad$ Graduate and above & 20 & 3.0 \\
\hline
\end{tabular}

Table-II

Distribution of the study subjects by clinical risk factors $(n=668)$

\begin{tabular}{lcc}
\hline Risk factors & Frequency & Percentage \\
\hline Diabetes mellitus & 209 & 31.3 \\
Hypertension & 267 & 40.0 \\
Dyslipidemia & 151 & 22.6 \\
Obesity & 28 & 4.2 \\
Smoking & 204 & 30.5 \\
Tobacco & 97 & 14.5 \\
Alcohol & 2 & 0.3 \\
Family history of CAD & 31 & 4.6 \\
H/O ischemic heart disease & 189 & 28.3 \\
Previous PTCA & 11 & 1.6 \\
Previous CABG & 10 & 1.5 \\
\hline
\end{tabular}

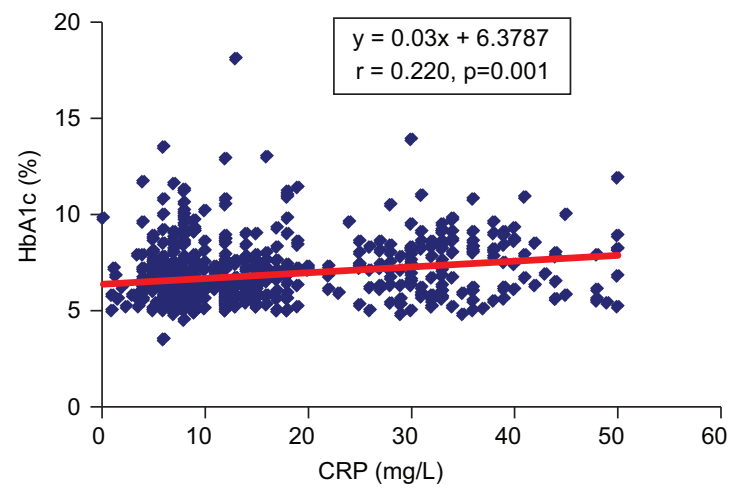

Fig.-1: Scatter diagram showing the positive correlation $(r=0.220, p=0.001)$ of $H b A 1 c$ with $\operatorname{CRP}(n=668)$.

Table III

Association between $\mathrm{HbA} 1 \mathrm{c}$ with $\mathrm{CRP}$ of the study population

\begin{tabular}{lccc}
\hline CRP & $<6.5 n(\%)$ & HbA1c & p value \\
\hline Normal $(<6 \mathrm{mg} / \mathrm{L})$ & $33(9.2)$ & $23(7.4)$ & $0.001^{\mathrm{s}}$ \\
Borderline (6-10 mg/L) & $188(52.4)$ & $99(32.0)$ & \\
High $(>10 \mathrm{mg} / \mathrm{L})$ & $138(38.4)$ & $187(60.5)$ & \\
\hline
\end{tabular}

Data were analyzed by Chi-square test, $\mathrm{s}=$ significant

Table-IV

Multi variable logistic regression analysis for severe $C A D$

\begin{tabular}{lcccc}
\hline & Adjusted & \multicolumn{2}{c}{$95 \% \mathrm{Cl}$} & $\mathrm{P}$ \\
\cline { 3 - 4 } & OR & Lower & Upper & $0.023^{\mathrm{s}}$ \\
\hline HbA1c (e"6.5) & 0.261 & 0.025 & 0.882 & $0.001^{\mathrm{s}}$ \\
CRP (>10 mg/L) & 30.222 & 8.874 & 99.389 & $0.045^{\mathrm{s}}$ \\
Diabetes mellitus & 0.103 & 0.011 & 0.953 & $0.935^{\text {ns }}$ \\
Hypertension & 1.059 & 0.268 & 4.181 & $0.653^{\text {ns }}$ \\
Dyslipidemia & 0.698 & 0.146 & 3.346 & $0.378^{\text {ns }}$ \\
Smoking & 0.547 & 0.143 & 2.092 & $0.001^{\mathrm{s}}$ \\
Constant & 0.007 & - & - & \\
\hline
\end{tabular}

$\mathrm{s}=$ significant, $\mathrm{ns}=$ not significant 


\section{DISCUSSION:}

Recently, inflammation has been implicated in the development and progression of atherosclerosis. From the pathological viewpoint, all stages i.e. initiation, growth and complications of the atherosclerotic plaque, may be considered as inflammatory responses to vascular endothelial injury. Being the major cause of mortality and morbidity in patients with T1DM 24 it is very important to study and monitor markers of inflammation to define patients at higher risk of vascular complications.

Glycemic control, BMI, LDL cholesterol, HDL cholesterol, triglycerides, and systolic blood pressure were defined as the determinants of inflammatory activity in type 1 diabetes. ${ }^{25,26}$

In this present study it was observed that most (65.0\%) of the patients belonged to age 41-60 years. The mean age was found $51.4 \pm 10.7$ years with range from $25-85$ years. Majority $(82.3 \%)$ patients were male and $390(58.4 \%)$ patients were illiterate. Similar report Muhammad et al. ${ }^{27}$ found mean age of the study population was $51.5 \pm 9.5$ years and most $(65.7 \%)$ of the patient were male.

In this study, among the risk factors, highest 267 (40.0\%) patients had hypertension followed by 209 (31.3\%) diabetes mellitus, 204 (30.5\%) smoker, 189 (28.3\%) H/O ischemic heart disease and 151 (22.6\%) dyslipidemia. This findings were also consistent with others studies like Razban et al. ${ }^{28}$; Muhammad et al. ${ }^{27}$ and Seyedian et al. ${ }^{29}$.

From this study, we cannot infer, whether poor glycemic control leads to inflammation or whether inflammation leads to higher glucose levels (or whether a third factor influences both). Prospective studies are needed to evaluate that question. However, either direction of causality would have important implications. If poor glycemic control leads to inflammation, then better glycemic control should lower inflammation and therefore lower the risk of cardiovascular complications.

In this study positive correlation was found $(r=0.220, p=$ 0.001 ) between $\mathrm{HbA1c}$ with CRP in CAD patients. Fawaz et al. ${ }^{30}$ found their study a positive correlation of inflammatory marker (CRP) and $\mathrm{HbA} 1 \mathrm{c}$ which supports other studies. ${ }^{2,31}$ This can be explained by the fact that $\mathrm{HbA} 1 \mathrm{c}$ reflects the biological activities of hyperglycemia and advanced glycation end products, all of which can induce inflammation. ${ }^{32}$ Hyperglycaemia has an indirect influence on atherosclerosis through lipid changes. It increases potentially atherogenic forms of small VLDL and small dense LDL which are susceptible to glycation and oxidation. However, chronic hyperglycaemia may be a separate risk factor for accelerated macroangiopathy. ${ }^{33}$ Roopakala et al. ${ }^{34}$ reported that positive correlation $(r=0.347, p=0.008)$ of $\mathrm{HbA} 1 \mathrm{c}$ with $\mathrm{CRP}$ in diabetic nephropathy.

Positive correlation coefficient between hemoglobin $\mathrm{A} 1 \mathrm{c}$ and CRP levels in studied patients $(r=0.371, p=0.05) .{ }^{35}$ Study done by Tutuncu et al. ${ }^{36}$ on comparison of hs- CRP levels in new Diabetes groups observed a positive correlation between hs-CRP levels and age, BMl, waist, hip, SBP, DBP, pulse, FPG, HbA1c, TG, non-HDL cholesterol; and there was a negative correlation with HDL-cholesterol and eGFR. Wu et al. ${ }^{17}$ reported that high levels of hs-CRP were correlated with high levels of $\mathrm{HbA} 1 \mathrm{c}$ and FPG in men and with only FPG in women.

In this study, high CRP was found higher (60.5\%) at $\geq 6.5$ percent $\mathrm{HbA} 1 \mathrm{c}$ level. The difference was statistically significant $(p<0.05)$. King et al. ${ }^{37}$ reported that elevated $\mathrm{HbA}(1 \mathrm{c})$ levels (e" $9.0 \%$ ) had a significantly higher percent of elevated CRP than people with low ( $<7 \%) \mathrm{HbA}(1 \mathrm{c})$ levels $(P<0.001)$.

Festa et al. ${ }^{38}$ found links between CRP and insulin resistance. Other studies have related hyperglycemia to inflammation by demonstrating simultaneous inflammation, endothelial dysfunction, and insulin resistance at the physiologic level. ${ }^{39,40}$ One of the several mechanisms proposed is oxidative stress on the endothelium, which promotes inflammation and is enhanced by hyperglycemia. ${ }^{41-43}$ The current study demonstrates that higher $\mathrm{HbA} 1 \mathrm{c}$ is significantly associated with elevation of CRP. These results imply a significant relation between inflammation and glycemic control in people with established CAD.

Multi variable logistic regression was found high $\mathrm{HbA} 1 \mathrm{c}$ had 0.261 (95\% Cl 0.025 to 0.882), high CRP had 30.222 (95\% $\mathrm{Cl} 8.847$ to 99.389$)$ and diabetes mellitus had 0.103 (95\% $\mathrm{Cl} 0.011$ to 0.953 ) times increase in odds having severe CAD (Double and triple vessel). Which were statistically significant $(p<0.05)$.

Therefore, detection of inflammatory marker and close observation of their glycemic control is essential to prevent cardiovascular complications. Early and effective prevention of cardiovascular disease will improve lifestyle with the emphasis on disease prevention.

\section{Conclusion:}

There is a positive correlation between serum levels of CRP and $\mathrm{HbA} 1 \mathrm{c}$ in CAD patients. Thus, aiming at good glycemic control and estimation of serum CRP levels will possibly be of help in planning early intervention, thereby preventing further complications which in turn may help preserve cardiac functions in ischemic heart disease patients. 


\section{Reference:}

1. Aribi M, Moulessehoul S, Kendouci-Tani M, Benabadji AB, Hichami A, Khan NA. Relationship between interleukin-1 beta and lipids in type 1 diabetic patients. Med Sci Monit 2007; 13: CR372-8.

2. Schoelin A, Siegbahn A, Lind L, et al. CRP and IL-6 concentrations are associated with poor glycemic control despite preserved beta-cell function during the first year after diagnosis of type 1 diabetes. Diabetes Metab Res Rev 2004; 20: 205-10.

3. ErbaggciAB, TarakçiogØlu M, Cokun Y, et al. Mediators of inflammation in children with type I diabetes mellitus: cytokines in type I diabetic children. Clin Biochem 2001; 34: 645-50.

4. Heinrich $P$, Castell J, Andus T. Interleukin- 6 and the acute phase response. Biochem J 1990; 265: 621-36.

5. Devaraj S, Jialal I. Alpha tocopherol supplementation decreases serum C-reactive protein and monocyte interleukin-6 levels in normal volunteers and type-2 diabetic patients. Free Rad Biol Med 2000; 29: 790-2.

6. Jialal I, Devaraj S, Venugopal SK. C-reactive protein: risk marker or mediator in atherothrombosis? Hypertension 2004; 44: 6-11.

7. Abdelmouttaleb I, Danchin N, llardo C, Aimone-Gastin I, Angioi M, Lozniewski A, et al. C-reactive protein and coronary artery disease: additional evidence of the implication of an inflammatory process in acute coronary syndromes. Am Heart J 1999;137: 346-51.

8. Ridker PM, Rifai N, Lowenthal SP. Rapid reduction of C-reactive protein with cerivastatin among 785 patients with primary hypercholesterolemia. Circulation 2001;103:1191-93.

9. Ridker PM, Glynn RJ, Hennekens CH. C-reactive protein adds to the predictive value of total and HDL cholesterol in determining risk of first myocardial infarction. Circulation1998; 97:2007-11.

10. Kervinen H, Palosuo T, Manninen V, Tenkanen L, Vaarala O, Manttari M. Joint effects of C-reactive protein and other risk factors on acute coronary events. Am Heart J 2001;141:580-85.

11. Ridker PM, Stampfer MJ, Rifai N. Novel risk factors for systemic atherosclerosis: a comparison of Creactive protein, fibrinogen, homocysteine, lipoprotein(a), and standard cholesterol screening as predictors of peripheral arterial disease. JAMA 2001;285:2481-85.
12. Pradhan AD, Manson JE, Rifai N, Buring JE, Ridker PM. C-reactive protein, interleukin-6, and risk of developing type 2 diabetes mellitus. JAMA 2001;286:327-34.

13. Barzilay JI, Abraham L, Heckbert SR, Cushman M, Kuller LH, Resnick HE, et al. The relation of markers of inflammation to the development of glucose disorders in the elderly: the Cardiovascular Health Study. Diabetes 2001;50:2384-89.

14. Ford ES. Body mass index, diabetes, and C-reactive protein among U.S. Adults. Diabetes Care 1999; 22:1971-77.

15. Grau AJ, Buggle F, Becher H, Werle E, Hacke W. The association of leukocyte count, fibrinogen and Creactive protein with vascular risk factors and ischemic vascular diseases. Thromb Res 1996;82:245-255.

16. Goldberg RB. Cardiovascular disease in diabetic patients. Med Clin North Am 2000;84:81-93.

17. Wu T, Dorn JP, Donahue RP, Sempos CT, Trevisan M. Associations of serum C-reactive protein with fasting insulin, glucose, and glycosylated hemoglobin: the Third National Health and Nutrition Examination Survey, 1988-1994. American Journal of Epidemiology, 2002; 155: 65-71.

18. Khaw KT, Wareham N, Luben R, Bingham S, Oakes S, Welch A, et al. Glycated hemoglobin, diabetes, and mortality in men in Norfolk cohort of European prospective investigation of cancer and nutrition (EPICNorfolk). BMJ. 2001;322:15-18.

19. Laakso M. Glycemic control and the risk for coronary heart disease in patients with non-insulin-dependent diabetes mellitus: the Finnish studies. Ann Intern Med. 1996;124:127-30.

20. Eeg-Olofsson K, Cederholm J, Nilsson PM, Zethelius B, Svensson AM, Gudbjornsdóttir S, et al. Glycemic control and cardiovascular disease in 7,454 patients with type 1 diabetes: an observational study from the Group Swedish National Diabetes Register (NDR). Diabetes Care. 2010;33:1640-6.

21. Selvin E, Steffes MW, Zhu H, Matsushita K, Wagenknecht L, Pankow J, et al. Glycated hemoglobin, diabetes, and cardiovascular risk in nondiabetic adults. N Engl J Med. 2010;362:800-11.

22. Rekeneire DN, Peila R, Ding J, Colbert LH, Visser M, Shorr RI, et al. Diabetes, hyperglycemia, and inflammation in older Individuals. The Health, Aging and Body Composition study. Diabetes Care 2006;29:1902-8. 
23. Schalkwijk CG, Poland DC, Van Dijk W, Kok A, Emeis $\mathrm{JJ}$, Drager AM, et al. Plasma concentration of Creactive protein is increased in Type I diabetic patients without clinical macroangiopathy and correlates with markers of endothelial dysfunction: evidence for chronic inflammation. Diabetologia 1999;42:351-7.

24. Hayaishi-Okano, Yamasaki $\mathrm{Y}$, Katakmi N, et al. Elevated C-reactive protein associates with earlystage carotid atherosclerosis in young subjects with type 1 diabetes. Diabetes Care 2002; 25: 1432-8.

25. Schram MT, Chaturvedi N, Schalkwijk C, et al.; EURODIAB Prospective Complications Study. Vascular risk factors and markers of endothelial function as determinants of inflammatory markers in type 1 diabetes: the EURODIAB Prospective Complications Study. Diabetes Care 2003; 26: 216573.

26. Schwab KO, Doerfer J, Hecker W, et al.; DPV Initiative of the German Working Group for Pediatric Diabetology. Spectrum and prevalence of atherogenic risk factors in 27,358 children, adolescents, and young adults with type 1 diabetes. Cross-sectional data from the German diabetes documentation and quality management system (DPV). Diabetes Care 2006; 29: 218-25.

27. Muhammad R, Masood A, Zaffar J, Butt U. Correlation of mean $\mathrm{HbA} 1 \mathrm{c}$ levels with severity of coronary arteries disease in diabetics. Pak Heart J. 2014; 47(4): 184-87.

28. Razban MM, Eslami M, Bagherzadeh A. The relationship between serum levels of hs-CRP and coronary lesion severity. Clujul Medical. 2016; 89(3): 352-64.

29. Seyedian SM, Ahmadi F, Dabagh R, Davoodzadeh H. Relationship between high-sensitivity C-reactive protein serum levels and the severity of coronary artery stenosis in patients with coronary artery disease. ARYA Atheroscler. 2016; 12(5): 231-7.

30. Fawaz L, Elwan AE, Kamel YH, Farid TM, Kamel A, Mohamed WA. Value of C-reactive protein and IL-6 measurements in type 1 diabetes mellitus. Arch Med Sci 2009; 5, 3: 383-90

31. Hansen TK, Thiel S, Knudsen ST, et al. Elevated levels of mannan-binding lectin in patients with type 1 diabetes. J Clin Endocrinol Metab 2003; 88: 4857-61.

32. Schalkwijk CG, Chaturvedi N, Twaafhoven H, Van Hinsbergh VW, Stehouwer CD. Amadori-albumin correlates with microvascular complications and precedes nephropathy in type 1 diabetic patients. Eur J Clin Invest 2002; 32: 500-6.
33. Nathan DM, Lachin J, Cleary P, et al. DCCT/EDIC Research Group. Intensive diabetes therapy and carotid intimamedia thickness in type 1 diabetes mellitus. N Engl J Med 2003; 348: 2294-303.

34. Roopakala MS, Pawan HR, Krishnamurthy U, Wilma Delphine Silvia CR, Eshwarappa M, Prasanna Kumar KM. Evaluation of High Sensitivity C-reactive Protein and Glycated Hemoglobin Levels in Diabetic Nephropathy. Saudi J Kidney Dis Transpl 2012;23(2):286-89.

35. Mandal S, Causevic A. The Correlation between CReactive Protein and Regulation of Glycemia in Type2 Diabetic Patients. Bulletin of the Chemists and Technologists of Bosnia and Herzegovina 2017;48:58.

36. Tutuncu Y, Satman I, Celik S, Dinccag N, Karsidag K, Telci A, et al. A Comparison of hs-CRP Levels in New Diabetes Groups Diagnosed Based on FPG, 2-hPG, or HbA1c Criteria. Journal of Diabetes Research. 2016, Article ID 5827041, 1-9.

37. King DE, Mainous AG, Buchanan TA, Pearson WS. C-Reactive Protein and Glycemic Control in Adults With Diabetes. Diabetes Care 2003; 26:1535-39.

38. Festa A, D'Agostino R Jr, Tracy RP, Haffner SM. Elevated levels of acutephase proteins and plasminogen activator inhibitor-1 predict the development of type 2 diabetes: the Insulin Resistance Atherosclerosis Study. Diabetes 2002; 51:1131-37.

39. Yudkin JS, Stehouwer CD, Emeis JJ, Coppack SW. C-reactive protein in healthy subjects: associations with obesity, insulin resistance, and endothelial dysfunction: a potential role for cytokines originating from adipose tissue? Arterioscler Thromb Vasc Biol 1999;19:972-78.

40. Fichtlscherer S, Rosenberger G, Walter DH, Breuer S, Dimmeler S, Zeiher AM. Elevated C-reactive protein levels and impaired endothelial vasoreactivity in patients with coronary artery disease. Circulation 2000;102:1000-1006.

41. Mohanty P, Hamouda W, Garg R, Aljada A, Ghanim H, Dandona P. Glucose challenge stimulates reactive oxygen species (ROS) generation by leucocytes. J Clin Endocrinol Metab 2000;85:2970-73.

42. Mohanty P, Ghanim H, Hamouda W, Aljada A, Garg R, Dandona P. Both lipid and protein intakes stimulate increased generation of reactive oxygen species by polymorphonuclear leukocytes and mononuclear cells. Am J Clin Nutr 2002;75:767-72.

43. Dandona $\mathrm{P}, \mathrm{Aljada} \mathrm{A}$. A rational approach to pathogenesis and treatment of type 2 diabetes mellitus, insulin resistance, inflammation, and atherosclerosis. Am J Cardiol 2001;90:27G-33G. 